\title{
Cascading disturbances in Florida Bay, USA: cyanobacteria blooms, sponge mortality, and implications for juvenile spiny lobsters Panulirus argus
}

\author{
Mark J. Butler IV ${ }^{1, *}$, John H. Hunt ${ }^{2}$, William F. Herrnkind ${ }^{3}$, Michael J. Childress ${ }^{3}$, \\ Rodney Bertelsen ${ }^{2}$, William Sharp ${ }^{2}$, Thomas Matthews ${ }^{2}$, Jennifer M. Field ${ }^{4}$, \\ Harold G. Marshall ${ }^{1}$ \\ ${ }^{1}$ Department of Biological Sciences, Old Dominion University, Norfolk, Virginia 23529-0266, USA \\ ${ }^{2}$ Florida Marine Research Institute, South Florida Regional Laboratory, Florida Department of Environmental Protection, \\ 2796 Overseas Highway, Suite 119, Marathon, Florida 33050, USA \\ ${ }^{3}$ Department of Biological Science, Florida State University, Tallahassee, Florida 32306, USA \\ ${ }^{4}$ Environmental Sciences Division, Oak Ridge National Laboratories, PO Box 2008, Oak Ridge, Tennessee 37831-6038, USA
}

\begin{abstract}
Florida Bay, the shallow lagoon separating mainland Florida and the Florida Keys, USA, is experiencing an unprecedented series of ecological disturbances. In 1991, following reports of other ecosystem perturbations, we observed widespread and persistent blooms of cyanobacteria that coincided with the decimation of sponge communities over hundreds of square kilometers. Juvenile Caribbean spiny lobsters Panulirus argus, among other animals, rely on sponges for shelter; the impact of sponge loss on the abundance of lobsters and their use of shelter, in particular, has been dramatic. The loss of sponges on 27 experimental sites in hard bottom habitat in central Florida Bay resulted in the redistribution of juvenile lobsters among the remaining shelters, an influx of lobsters into sites where artificial shelters were present, and a decline in lobster abundances on sites without artificial shelters. Diver surveys of sponge damage at additional sites in central Florida Bay confirmed that the sponge die-off was widespread and its occurrence coincided with areas that had been exposed to the cyanobacteria bloom. This cascade of disturbances has dramatically altered the community structure of affected hard bottom areas and demonstrates the coupled dynamics of this shallow marine ecosystem.
\end{abstract}

KEY WORDS: Florida Bay - Sponge - Spiny lobster - Disturbance C Cyanobacteria $\cdot$ Artificial shelters . Algal bloom

\section{INTRODUCTION}

Florida Bay, the shallow subtropical lagoon lying between the south Florida mainland and the Florida Keys (USA), is recognized for its productivity, diversity, and role as a marine nursery (Holmquist et al. 1989, Thayer \& Chester 1989). Hard bottom habitat intersperses with seagrass meadows throughout much of

•E-mail: mjb100f@oduvm.cc.odu.edu the bay and together these habitats serve as nurseries and foraging grounds for numerous species of fish and crustaceans. Sponges, octocorals, small hard corals, and patches of macroalgae are characteristic features of Florida Bay's hard bottom habitat, which includes areas of exposed calcium carbonate rock pocked with solution holes and overlain by a thin veneer of carbonate sediment. Sponges are a particularly dominant structural feature of this habitat (Chiappone \& Sullivan 1994, Field \& Butler 1994) and function as efficient filterers of small $(<5 \mathrm{~mm})$ planktonic particles (Reiswig 
1971). Most sponges, such as the massive ( $>1 \mathrm{~m}$ diameter and height) loggerhead sponge Speciospongia vesparium, shelter numerous animals commensally within their internal chambers (Pearse 1950, Erdman \& Blake 1987, Uriz et al. 1992). Other macrofauna shelter within crevices beneath sponges and include: stone crabs Menippe mercenaria, spider crabs Mithrax spp., toadfish Opsanus beta, octopus Octopus spp., and juvenile Caribbean spiny lobster Panulirus argus. Spiny lobsters are of particular interest because they depend on sponges and other hard bottom structures for shelter during their early life history (Herrnkind et al. 1994), are major predators of benthic fauna (Herrnkind et al. 1988), and support the most valuable fishery in Florida (Hunt 1994).

Florida Bay has undergone substantial ecological change over the past 2 decades, especially within the last few years (see Boesch et al. 1993). The best known, although still insufficiently understood, change in the ecosystem is the death of thousands of hectares of seagrass Thalassia testudinum, first documented in 1987 (Zieman et al. 1988, Robblee et al. 1991, Fourqurean et al. 1992, and others). Extensive blooms of cyanobacteria and phytoplankton have since developed in the north central region of the bay (Butler et al. 1994). For months at a time each year since at least 1991, cyanobacteria blooms have swept over extensive portions of the bay north of the middle Keys, an area well documented as productive lobster nursery habitat (Davis \& Dodrill 1989, Field \& Butler 1994, Herrnkind \& Butler 1994, and others). We subsequently recorded the death of a variety of sponge species throughout the hard bottom habitat covered by these blooms and coincident shifts in the abundance and shelter use of juvenile spiny lobsters. Here we report on the sponge dieoff, document local changes in juvenile spiny lobster shelter use and abundance, and discuss associated ecological events.

\section{METHODS AND RESULTS}

In mid-November 1991, a phytoplankton bloom swept southward into an area near the Lower Arsnicker Keys $\left(24^{\circ} 55.0^{\prime} \mathrm{N}, 80^{\circ} 49.4^{\prime} \mathrm{W}\right)$ where we were studying lobster recruitment (Fig. 1). Analysis of water samples using light, epifluorescence, and scanning electron microscopy confirmed that unicellular and chain-forming ( 2 to 8 cell chains; each cell $<2 \mathrm{~mm}$ long) cyanobacteria dominated this bloom. Cyanobacteria cell densities in the bloom reached $10^{9}$ cells $^{-1}$ compared to background densities of $<10^{4}$ cells $^{-1}$ in areas outside the bloom but within Florida Bay. Chlorophyll a (chl a) concentrations within the bloom were 18 to $22 \mathrm{mg} \mathrm{l}^{-1}$ as compared to values of $<1$ to

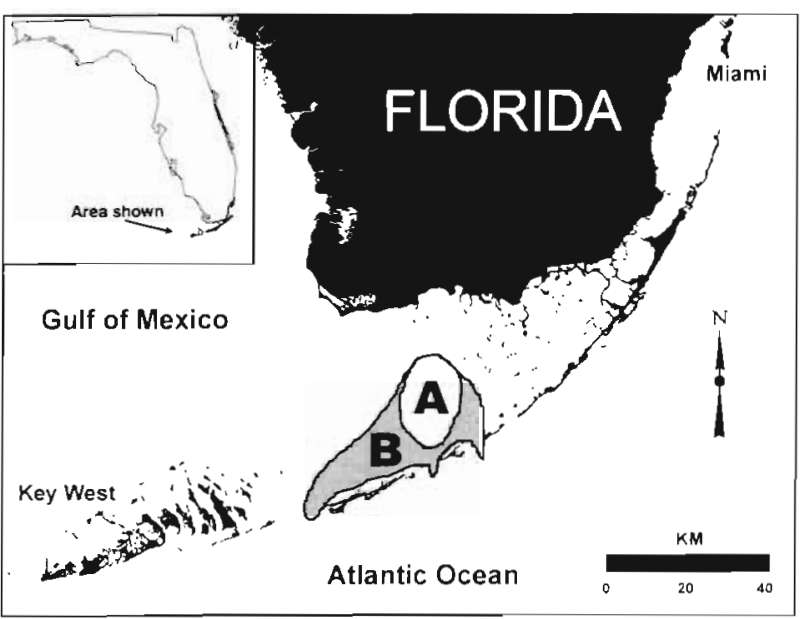

Fig. 1. Maximal spatial extent of the November 1991 to January 1992 cyanobacteria bloom (water mass A) and the October 1992 to May 1993 cyanobacteria bloom (water mass B) in Florida Bay (USA). The boundaries of each bloom were determined from biweekly aerial surveys and are approximate because the boundaries were dynamic and continually changing

$3 \mathrm{mg} \mathrm{l}^{-1}$ outside of the bloom. The bloom reduced underwater visibility from around $8 \mathrm{~m}$ to $<0.5 \mathrm{~m}$, and prevented us from conducting our regular field surveys of lobsters until February 1992.

We had been following juvenile spiny lobster population dynamics and shelter habitation patterns for 6 mo prior to the bloom (since May 1991) in an experiment conducted at 27 separate patches of hard bottom habitat, each 0.07 to 0.2 ha in area and scattered over $>1 \mathrm{~km}^{2}$ of seafloor. As part of that study, we had manipulated the abundance of shelters for juvenile lobsters by adding different densities of small $(40 \times 20 \times 10 \mathrm{~cm})$ cement block artificial shelters to 21 of the 27 study sites. No artificial shelters were placed at the 6 remaining sites that served as controls in the experiment. We censused lobsters monthly by searching (using SCUBA) every potential shelter (e.g. artificial shelter, sponge, octocoral, coral head, solution hole) within each site and capturing all lobsters encountered. Pertinent population information (e.g. carapace length, sex, injuries, and molt conditionj was recorded for all captured lobsters before we tagged (coded spaghetti tag) and returned them to the shelter type from which they came. Our experimental sites were sufficiently separated to be considered independent, since no juvenile lobsters (i.e. those $<40 \mathrm{~mm}$ carapace length) tagged on one site were ever recovered on a different one. We also tagged and mapped every shelter occupied by a lobster. By the time the bloom entered our study area, we had mapped 645 natural dens (369 of which were sponges) and had effectively reached an asymptote in the rumber of dens on each site. Thus, we had a rela- 
tively complete map of all the potential lobster shelters on those 27 sites and had mapped the position of nearly every loggerhead sponge Speciospongia vesparium and vase sponge Ircinia campana, as well as most of the sheepswool Hippiospongia laehna, stinker Ircinia felix, gray-purple Spinosella vaginalis, and branch candle Vergangia longissima sponges. Sponges were the most numerous, large structures present at our sites and, on average, covered $9 \%$ of the seafloor in hard bottom habitat throughout Florida Bay (Field \& Butler 1994, Herrnkind \& Butler 1994).

When the bloom dissipated in February 1992, we revisited our sites and discovered that many of the sponges were dead or damaged. Over $80 \%$ of the vase sponges, candle sponges, and commercial sponges died, whereas $>40 \%$ of the loggerhead sponges were
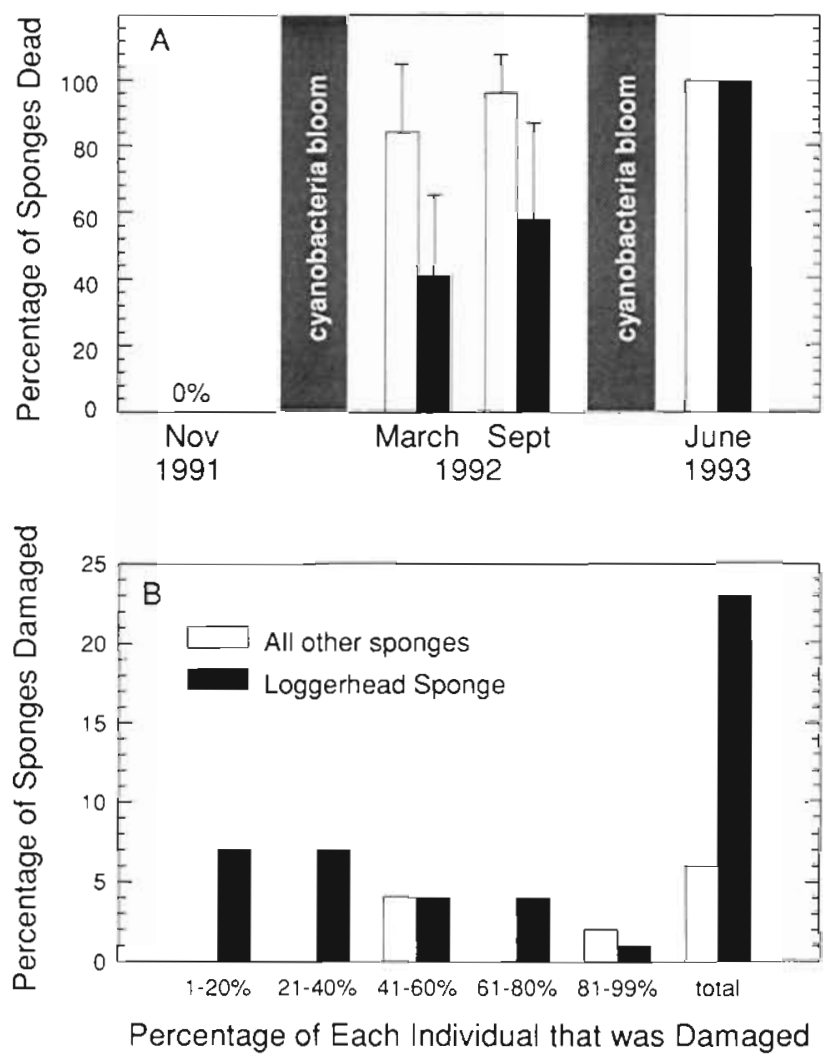

Fig. 2. (A) Percentage (mean $\pm 1 \mathrm{SD}$ ) of the sponge community (loggerhead sponges vs all other sponges combined) that was dead at the Lower Arsnicker Keys study site prior to the first bloom of cyanobacteria (November 1991), shortly after the first cyanobacteria bloom (March 1992), prior to the second bloom of cyanobacteria (September 1992), and after the second cyanobacteria bloom (June 1993). (B) Percentage of sponges (loggerhead sponges vs all other sponges combined) that were damaged but alive in March 1992 following the first bloom of cyanobacteria. Total percentage of sponges that were damaged is shown, as well as a break-down of the degree of damage to individual sponges, depicted as the percentage of that sponge that was damaged killed and another 23\% partially damaged (Fig. 2). Dead sponges quickly deteriorated into spicule skeletons that soon disintegrated. Some of the partially damaged loggerhead sponges healed in disfigured shapes, but many sponges subsequently died and disappeared by September 1992 (Fig. 2).

To determine whether the sponge mortality we observed was widespread, we surveyed an additional 10 hard bottom stations within a $300 \mathrm{~km}^{2}$ region known (based on aerial surveys and corresponding water samples; J. Hunt unpubl. data) to have been encompassed by the cyanobacteria bloom. At each station, we surveyed sponges or their remains during timed dives to determine the proportion of sponges killed or damaged. A total of $71 \%(1 \mathrm{SD}=20 \%)$ of the sponges at 5 stations near the center of the bloom were dead, whereas only $5 \%(1 \mathrm{SD}=5 \%)$ were damaged at stations near the periphery of the bloom. A few dead or damaged sponges were found at 9 of the 10 stations.

An even larger and more persistent bloom erupted nearly a year later in October 1992, but did not dissipate until May 1993. Weekly aerial surveys conducted in 1992 by the Florida Department of Environmental Protection - Florida Marine Research Institute and The Nature Conservancy indicated that the 1992 to 1993 cyanobacteria bloom developed in north central Florida Bay, although its subsequent position was quite dynamic and at times swept south to the Florida Keys and beyond to the coral reef fringing the keys (Fig. 1). Analysis of water samples taken at 15 stations throughout Florida Bay again confirmed that cyanobacteria (possibly Synechococcus elongatus; K. Steidinger, Florida Marine Research Institute, pers. comm.) dominated the bloom water, and chl a concentrations were near $30 \mathrm{mg} \mathrm{l}^{-1}$ in the bloom's center versus values $<2 \mathrm{mg} \mathrm{l}^{-1}$ at stations outside the bloom. This bloom also resulted in massive sponge mortality.

All of the sponges remaining at our Lower Arsnicker Keys experimental sites after the 1991 to 1992 bloom were destroyed by the time the 1992 to 1993 bloom abated (Fig. 2A). Similar effects were observed at other locations in the bay. For example, during the summer of 1992, prior to the second bloom, we had mapped the exact position of each sponge and octocoral at two 0.6 ha hard bottom sites that we had not previously examined. One site $\left(24^{\circ} 54.6^{\prime} \mathrm{N}, 80^{\circ} 49.4^{\prime} \mathrm{W}\right)$ just a few kilometers south of our experimental sites near the Lower Arsnicker Keys, was engulfed by the bloom for 2 mo in 1992 (late September to November 1992). The 35 sponges (4 species) resident on this site were all killed. The second site $\left(24^{\circ} 50.5^{\prime} \mathrm{N}, 80^{\circ} 47.8^{\prime} \mathrm{W}\right)$, another $10 \mathrm{~km}$ southeast and adjacent to Fiesta Key along the main Florida Keys tract, was only exposed to the bloom for $2 \mathrm{wk}$ (October 30 to November 13, 1992), yet in that time $10 \%$ of the 202 sponges ( 6 species) 

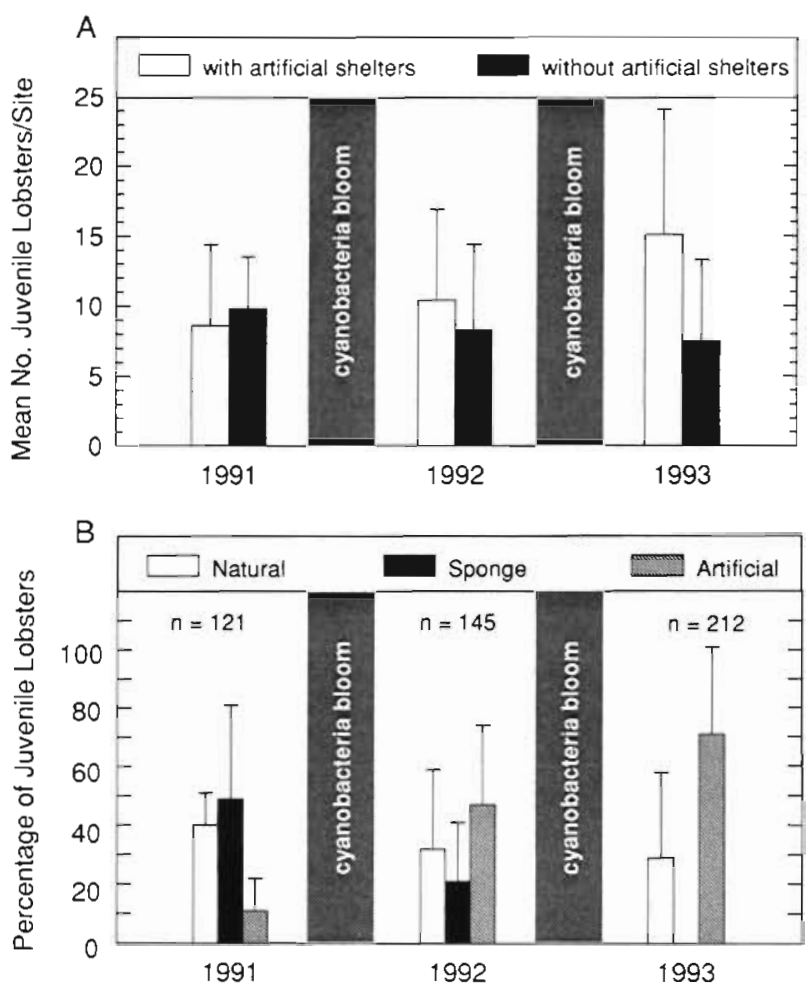

Fig. 3. (A) Mean ( $\pm 1 \mathrm{SD}$ ) number of juvenile spiny lobsters in hard bottom sites with ( $n=14$ sites) and without ( $n=6$ sites) artificial shelters observed during July 1991, 1992, and 1993. (B) Successive annual (July 1991 to 1993) changes in the pattern of shelter use by juvenile spiny lobsters in relation to 2 cyanobacteria bloom events and the subsequent mass mortality of sponges. Plotted are the mean percentages ( \pm 1 SD) of juvenile lobsters utilizing natural shelters (excluding sponges), only sponges, or artificial shelters on 14 hard bottom sites in Florida Bay. Total number of juvenile lobsters (N) observed during each census period are shown above the histograms for each year

at the site were killed or damaged. Cyanobacteria blooms were observed again in 1994 and 1995 in essentially the same region as earlier blooms, but there were no sponges left at any of our previous experimental sites with which to gauge the effect of these blooms on the sponge communities. Thus, the cyanobacteria blooms and resultant sponge loss have dramatically changed the physical structure of the hard bottom habitat in central Florida Bay.

The distribution of lobsters among natural shelters, sponges, and artificial shelters changed significantly in response to the sponge die-off, particularly on the sites supplied with artificial shelters $(\mathrm{p}<0.0001$; $\mathrm{df}=2,37$; $F=19.33,18.30,57.53$ in separate 1 -factor repeatedmeasures ANOVAs on the proportion of lobsters dwelling in natural shelters, artificial shelters, and sponges, respectively; the data were transformed to ranks prior to analysis; Conover \& Iman 1981). For example, in July 1991 prior to the first sponge die-off, $89 \%$ of the juvenile lobsters occupied natural shelters on sites supplied with artificial shelters and half (49\%) of those lobsters were under sponges (Fig. 3B). At that time, only $11 \%$ of the lobsters inhabited artificial shelters. By July 1992, following the first sponge die-off, nearly half $(47 \%)$ of the juvenile lobsters were found in artificial shelters with a concomitant decline in lobsters found in the remaining natural structures (Fig, 3B). Only $29 \%$ of the juvenile lobsters occupied natural dens following the complete loss of sponges on our sites after the second cyanobacteria bloom; most (71\%) of the lobsters sheltered within artificial shelters (Fig. 3B). Once the sponges died, and in the absence of artificial shelter, lobsters sheltered primarily in solution holes and under coral heads.

The numerical response of the juvenile spiny lobster population to sponge loss varied among our experimental sites, depending on the availability of alternative natural and artificial shelters (Fig. 3). Lobster abundance fell $23 \%$ on control sites without artificial shelters, but increased $76 \%$ at the 14 sites containing artificial structures (Fig. 3A). This difference in lobster abundance among years (1991 to 1993) and between sites with and without artificial shelters was marginally significant statistically $(\mathrm{p}=0.077 ; F=2.75$; $\mathrm{df}=2,36$; for the year $\times$ treatment interaction term in a 2 -factor repeated-measures ANOVA conducted on square root transformed data). Yet, because the power of this test (0.42) was low and the magnitude of the difference in lobster abundance at sites before and after the bloom was high, the probability of a Type II error in this analysis is high. Acceptance of the null hypothesis that lobster abundance did not change on sites after the sponge die-off is therefore circumspect. To investigate this issue further, we are conducting surveys of juvenile lobster abundance and hard bottom habitat structure at sites throughout the Florida Keys, many of which were surveyed prior to the first cyanobacteria bloom.

\section{DISCUSSION}

Evidence is mounting that the south Florida ecosystem is experiencing environmental disturbances of unprecedented magnitude (Walters et al. 1992, Boesch et al. 1993). The list of disturbances must now include the development of dense cyanobacteria blooms, degradation of sponge communities, and changes in juvenile lobster population dynamics that we observed in central Florida Bay. There is considerable debate over what caused the deterioration of the region's marine ecosystem, including the events that triggered the algal blooms that are wracking Florida Bay. The cyanobacteria blooms now occurring in the central bay 
may be linked through advective processes (Tomasko \& Lapointe 1994) to western Florida Bay where phosphorus-rich water (Fourqurean et al. 1992, 1993, Lapointe et al. 1994) flowing southeast from the Gulf of Mexico meets the bay (Smith 1994). A mass of turbid water also exists in the western bay (Boesch et al. 1993), but unlike the cyanobacteria blooms in the central bay, it is constituted of suspended sediments and diatoms (predominantly Rhizosolenia sp.; Steidinger pers. comm.). Alternatively, the cyanobacteria blooms in central Florida Bay may have been sparked by nutrients liberated from the aftermath of the seagrass dieoffs. Seagrass die-offs occur in areas where the cyanobacteria blooms originate, begin shortly before the cyanobacteria blooms, and are most severe during late summer to early fall when the blooms appear (Robblee et al. 1991, Carlson et al. 1994, Thayer et al. 1994). These hypotheses are not mutually exclusive. The cyanobacteria blooms in the central bay may be caused by seagrass die-offs that may be in turn related to high seagrass density, disease, and declining water quality attributable to changing climate and the infusion of nutrient-rich water from the western bay (Tomasko \& Lapointe 1994, Zieman et al. 1994). Although the cause of the cyanobacteria blooms is debatable, they exist and their occurrence corresponds with sponge mortality and changes in juvenile spiny lobster population dynamics, as reported here.

We do not know how the sponges are killed. Previous instances of mass sponge mortalities in central Florida, the Bahamas, and the Mediterranean were attributed to a variety of infections (Lauchner 1980, Peters 1993), usually activated by deleterious environmental conditions such as low salinity, abnormal temperature, organic pollution, or heavy sedimentation (Storr 1964, Hummel et al. 1988, Vincente 1989, Vacelet et al. 1994). No previous reports of sponge mass mortality were associated with blooms of planktonic cyanobacteria. Some cyanobacteria, including Synechococcus, can be toxic to marine animals (Mitsui et al. 1989), but we did not witness any unusual mortality of fish or other invertebrates that might suggest the occurrence of a toxic bloom. Perhaps the exceptionally dense and persistent blooms of cyanobacteria that occurred in the otherwise clear tropical water of the Florida Keys blocked filtration and feeding by the sponges. Cyanobacteria have a sticky, mucilaginous sheath and in sufficient concentrations could obstruct the internal canal system of the sponge or impair choanocyte (flagellated filtration cell) or archaeocyte (phagocytic cell) functions. Stress such as this renders sponges susceptible to viral (Vacelet \& Gallissian 1978), bacterial (Vacelet et al. 1994), cyanobacterial (Rutzler 1988), or fungal infections that can destroy weakened sponges. In fact, it has been suggested that commensal bacteria that normally digest necrotic sponge tissue may become virulent and digest living tissue under unfavorable environmental conditions (Vacelet et al. 1994).

Regardless of how the sponges are killed, damage to the sponge community in the middle Florida Keys may foreshadow significant long-term effects on this ailing ecosystem. For example, species that live commensally with sponges are presumably now missing from hundreds of square kilometers of Florida Bay. Other impacts attributable to sponge loss may include changes in water chemistry, nutrient cycling, and microplanktonic assemblages that can be affected by sponge filter feeding and excretion. Unfortunately, the return to pre-bloom conditions may take a decade or more, both because of the slow recruitment and growth of sponges and because recurrent blooms have thwarted the rebound of the sponge community.

The long-term impact of sponge loss on spiny lobster recruitment in south Florida is also uncertain. Shelter such as that provided by sponges reduces the risk of predation to juvenile lobsters (Herrnkind \& Butler 1986, Eggleston \& Lipcius 1992, Smith \& Herrnkind 1992, Mintz et al. 1994). In the wake of the sponge dieoff, juvenile lobsters increasingly occupied the artificial dens we provided on our experimental sites and the abundance of lobsters on these sites increased, presumably from immigration of lobsters from the surrounding impacted natural areas. During the same period, lobster abundance on control sites without artificial shelters appeared to decline suggesting that the availability of alternative natural shelters was insufficient to forestall increased emigration or mortality. Subadult and adult lobsters are nomadic (Herrnkind 1980), but juvenile spiny lobsters show strong site fidelity (Yoshimura \& Yamakawa 1988, Forcucci et al. 1994, Norman et al. 1994). In the months prior to the sponge die-off, we tagged $>2500$ lobsters and only 9 lobsters, all subadults, had moved from one site to another. We hypothesize that unless alternative natural shelters (e.g. solution holes, coral heads) are present in sufficient numbers, juvenile lobsters will emigrate from impacted areas or occupy otherwise infrequently used and presumably less protective structures. In either case, we hypothesize that predation will increase on the vulnerable small juveniles over the region where sponge loss was extreme. If so, juvenile lobster abundance will decline in the region relative to what it would have been. Our continuing studies will allow us to better define the impact of sponge loss and habitat change on spiny lobster population structure and dynamics, but research on other aspects of this ailing ecosystem is also necessary before the causal links in this cascade of disturbances can be unequivocally demonstrated. 
Acknowledgements. This research was made possible by a Florida Sea Grant award (B/LR-B-30A) to M.B. and W.H. and by funds provided to J.H. by the Florida Department of Environmental Protection, Florida Marine Research Institute from spiny lobster recreational fishing licenses. We thank P. Carlson, $M$. Robblee, and J. Zieman for sharing their views, and are also grateful for comments by R. Birdsong, D. Camp, L. French, K. Ruetzler, and 3 anonymous reviewers on earlier drafts of this manuscript.

\section{LITERATURE CITED}

Boesch DF, Armstrong NE, D'Elia CF, Maynard NG, Paerl HN, Williams SL (1993) Deterioration of the Florida Bay ecosystem: an evaluation of the scientific evidence. Report to the Interagency Working Group on Florida Bay, Department of the Interior, National Park Service, Washington, DC

Butler MJ IV, Herrnkind WF, Hunt JH (1994) Sponge mass mortality and Hurricane Andrew: catastrophe for juvenile spiny lobsters in south Florida? Bull mar Sci 54:1073

Carlson PR, Yarbro LA, Barber TR (1994) Relationship of sediment sulfide to mortality of Thalassia testudinum in Florida Bay. Bull mar Sci 54:733-746

Chiappone M, Sullivan KM (1994) Ecological structure and dynamics of nearshore hard-bottom communities in the Florida Keys. Bull mar Sci 54:747-756

Conover WJ, Iman RL (1981) Rank transformations as a bridge between parametric and nonparametric statistics. Am Stat 35:124-129

Davis GE, Dodrill JW (1989) Recreational fishery and population dynamics of spiny lobsters, Panulirus argus, in Florida Bay, Everglades National Park, 1977-1980. Bull mar Sci $44: 78-88$

Eggleston DB, Lipcius RN (1992) Shelter selection by spiny lobster under variable predation risk, social conditions, and shelter size. Ecology 73:992-1011

Erdman RB, Blake NJ (1987) Population dynamics of the sponge-dwelling alpheid Synalpheus longicarpus, with observations on $S$. brooksii and $S$. pectiniger, in shallowwater assemblages of the eastern Gulf of Mexico. J crust Biol 7:328-337

Field JM, Butler MJ IV (1994) The influence of temperature, salinity, and larval transport on the distribution of juvenile spiny lobsters, Panulirus argus, in Florida Bay. Crustaceana $67: 26-45$

Forcucci D, Butler MJ IV, Hunt JH (1994) Population dynamics of juvenile Caribbean spiny lobster, Panulirus argus, in Florida Bay, FL (USA). Bull mar Sci 54:805-818

Fourqurean JW, Jones RD, Zieman JC (1993) Processes influencing water column nutrient characteristics and phosphorus limitation of phytoplankton biomass in Florida Bay, FL, USA: inferences from spatial distributions. Estuar coast Shelf $\mathrm{Scl}$ 36:295-314

Fourqurean JW, Zieman JC. Powell GVN (1992) Phosphorus limitation of primary productıvity in Florida Bay: evidence from C:N:P ratios of the dominant seagrass. Thalassia testudinum. Limnol Oceanogr 37:162-171

Hermkind WF (1980) Spiny lobsters: patterns of movement In: Cobb JS, Phillips BF (eds) The biology and management of lobsters, Vol. 1 Academic Press, New York, p $349-407$

Herrnkind WF, Butler MJ IV (1986) Factors regulating postlarval settlement and juvenile microhabitat use by spiny lobsters, Panulirus argus. Mar Ecol Prog Ser 34:23-30

Herrnkind WF, Butler MJ IV (1994) Settlement of spiny lob- sters, Panulirus argus in Florida: pattern without predictability. Crustaceana 67:46-64

Herrnkind WF, Butler MJ IV, Tankersley RA (1988) The effects of siltation on the recruitment of spiny lobsters, Panulirus argus. Fish Bull US 86:331-338

Hermkind WF, Jernakoff P, Butler MJ IV (1994) Puerulus and post-puerulus ecology. In: Phillips B, Cobb S, Kittaka J (eds) Spiny lobster management. Blackwell Press, Oxford, p 213-229

Holmquist JG, Powell GVN, Sogard SM (1989) Decapod and stomatopod communities of seagrass-covered mudbanks in Florida Bay: inter- and intra-bank heterogeneity with special reference to isolated subenvironments. Bull mar Sci $44: 251-262$

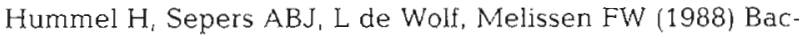
terial growth on the marine sponge Halichondria panicea induced by reduced waterflow rate. Mar Ecol Prog Ser 42: $195-198$

Hunt JH (1994) Status of the fishery for Panulirus argus in Florida. In: Phillips B, Cobb S, Kittaka J (eds) Spiny lobster management. Blackwell Press, Oxford, p 1.58-168

Lapointe BE, Tomasko DA, Matzie WR (1994) Eutrophication and trophic state classification of seagrass communities in the Florida Keys. Bull mar Sci 54:696-717

Lauchner G (1980) Diseases of Porifera. In: Kinne $O$ (ed) Diseases of marine animals, Vol I. Wiley, Chichester, p $139-165$

Mintz JD, Lipcius RN, Eggleston DB, Seebo MS (1994) Survival of juvenile Caribbean spiny lobster: effects of shelter size, geographic location, and conspecific abundance. Mar Ecol Prog Ser 112:255-266

Mitsui A, Rosner D, Goodman A, Reyes-Vasquez G, Kusumi T, Kodama T, Nomoto K (1989) Hemolytic toxins in marine cyanobacterium Synechococcus sp. In: Okaichi C Anderson $\mathrm{P}$, Nomoto K (eds) Red tides: biology, environmental science, and toxicology. Elsevier Sci Pub, New York, $p$ $367-370$

Norman CP, Yamakawa H, Yoshimura T (1994) Habitat selection, growth rate, and density of juvenile Panulirus japonicus (Von Siebold, 1824) (Decapoda, Palinuridae) at Banda, Chiba Prefecture, Japan. Crustaceana 66:366-383

Pearse AS (1950) Notes on the inhabitants of certain sponges at Bimini. Ecology 31:149-151

Peters EC (1993) Diseases of other invertebrate phyla: Porifera, Cnidaria, Ctenophore, Annelida, Echinodermata. In: Couch JA, Fournie JW (eds) Pathobiology of marine and estuarine organisms. CRC Press, Boca Raton, FL, p $393-449$

Reiswig HM (1971) Particle feeding in natural populations of three marine demosponges. Biol Bull 141:568-591

Robblee MB, Barber TR Carlson PR Jr, Durako MJ, Fourqurean JW, Muehlstein LK, Porter D, Yarbro LA. Zieman RT, Zieman JC (1991) Mass mortality of the tropical seagrass Thalassia testudinum in Florida Bay (USA). Mar Ecol Prog Ser 71:297-299

Ruetzler K (1988) Mangrove sponge disease induced by cyanobacterial symbionts: failure of a primitive immune system? Dis aquat Org 5:143-149

Smith KN, Herrnkind WF (1992) Predation on early juvenile spiny lobsters, Panulirus argus (Lat.): influence of size and shelter. J exp mar Biol Ecol 64:1-16

Smith NP (1994) Long-term Gulf-to-Atlantic transport through tidal channels in the Florida Keys. Bull mar Sci 54: 602-609

Storr JF (1964) Ecology of the Gulf of Nexico commercial sponges and its relation to the fishery. US Fish Wildl Serv Spec Scient Rep 466:1-73 
Thayer GW, Chester AJ (1989) Distribution and abundance of fishes among basin and channel habitats in Florida Bay. Bull mar Sci 44:200-219

Thayer GW, Murphey PL, LaCroix MW(1994) Responses of plant communities in western Florida Bay to the die-off of seagrasses. Bull mar Sci 54:718-726

Tomasko DA, Lapointe BE (1994) An alternative hypothesis for the Florida Bay seagrass die-off. Bull mar Sci 54:1086

Uriz M, Rosell JD, Maldonado M (1992) Parasitism, commensalism, or mutualism? The case of Scyphozoan (Coronatae) and horny sponges. Mar Ecol Prog Ser 81. $247-255$

Vacelet J, Gallisasian MF (1978) Virus-like particles in cells of the sponge Verongia cavernicola (Demospongiae, Dictyoceratida) and accompanying tissue changes. J Invertebr Pathol 31:246-254

Vacelet J, Vacelet E, Gaino E, Galliassian MF (1994) Bacterial attack of spongin skeleton during the 1986-1990 Mediterranean sponge disease. In: van Soest RWN, van Kempen

This article was presented by K. L. Heck Ir (Senior Editorial Advisor), Dauphin Island, Alabama, USA
TMG, Braekman JC (eds) Sponges in time and space Balkema Publ, Rotterdam, p 355-362

Vincente VP (1989) Regional commercial sponge extinctions in the West Indies: are recent climatic changes responsible? PSZN 1: Mar Ecol 10:179-191

Walters C, Gunderson L, Holling CS (1992) Experimental policies for water management in the Everglades. Ecol Appl 2:189-202

Yoshimura T, Yamakawa $\mathrm{H}$ (1988) Microhabitat and behavior of settled pueruli and juveniles of the Japanese spiny lobster, Panulirus japonicus at Kominato, Japan. J crust Biol 8:524-531

Zieman JC, Davis R, Fourqurean JW, Robblee MB (1994) The role of climate in the Florida Bay seagrass die-off. Bull mar Sci $54: 1088$

Zieman JC, Fourqurean JW, Robblee M, Durako M, Carlson P, Porter D, Zieman R, Muhlstein L, Powell G (1988) A catastrophic die-off of seagrasses in Florida Bay and Everglades National Park. Trans Am geophys Un 69:1111

Manuscript first received: September 22, 1993

Revised version accepted: May 30, 1995 